\title{
The Future Library circa 1989-1993
}

\section{Robert Wolf*}

$\Lambda$ nyone who has ever attended a library conference has the opportunity to sit through the "what will the future hold for libraries?" session that seems to be a conference standard. At a recent conference I heard the OPAC was dead and social tagging will replace cataloging. Is it? Will it? I don't know. This gave me an idea. I thought it might be interesting to look at some predictions from times gone by to see how accurate they were. Should I really believe them when they say the OPAC is dead, or have the seers of the library world been less than realistic in their premonitions? Let's take a look at three predictions from the mid-1980s through the early 1990s and see how accurate their predictions have been.

\section{6}

Irene Hoadley, the director of the Sterling C. Evans Library at Texas A\&M University, described the library of tomorrow as increasingly digital with smaller, more concise print collections and therefore not requiring larger facilities. Most librarians I have talked to over the years would tend to disagree. Library space is still at a premium. Yes, a greater percentage of our collections are now online; however, the need for print materials has not disappeared. E-books have not caught on as well as many predicted. On the other hand, print serials collections have dwindled in most libraries. Fromat, however, is not the only issue driving serial collections: cost has also been a factor.

Hoadley stated that with the increasing use of electronic resources the library will function less as a physical destination and more as an online service point, further reducing the need for space. She believed users would become more self-sufficient. I would have to disagree with this prediction. If anything, libraries have tried to become more of a destination on campus, maybe not in the traditional academic sense, but as a social gathering place. Libraries have added cafés and coffee bars, more computers and movies to attract students. Also, with the variety and complexity of tools and resources available to them, users are less likely to become self-sufficient and will initially need more guidance.

According to Hoadley, the library of the future will offer a greater variety of services and will provide 24 hour per-day access. Many institutions with sufficient staffing and funds currently provide 24/7 access.

She emphasized the increased role of instructional services which would go beyond basic bibliographic instruction and include computer literacy. We can see this working today in what many would term the information commons. Though not the moldel for all libraries, a significant number are heading in this direction. It

\section{"It's hard to make predictions, especially about the future." - Yogi Berra}

is definitely a trend. Interestingly enough I recently attended a conference where the presenter predicted the end of instructional services. I guess we'll have to wait to see how this one pans out.

\section{9}

The next prediction was given to us by Herbert White, who at the time was the Dean of the School of Library and Information Science at Indiana University. White, like Hoadley, stated electronic resources would continue to grow at a rapid rate. Databases would become more complex and more interdisciplinary but would have simpler interfaces. I think this is partially true. There are a number of large aggregator databases available. However, the subjectspecific databases have not disappeared. If anything, they seem to be on the rise. We have seen an attempt by database vendors to create simpler user interfaces. Many have gone to a Google-like search interface as the default, with the advanced search hidden in a tab. There has also been a growing use of federated search systems which provide one relatively simple interface that can be used to search multiple databases at once. So in a sense maybe White was right: databases aren't necessarily interdisciplinary, but they are combined in a way by federated searching.

According to White, in order to compete with commercial information providers the library of the future will become an information supermarket and concern itself less with format and more with access. Users are looking for the one-stop shopping experience. I'm not sure how we could ignore format, but I do believe we are heading in the supermarket direction. Today's libraries not only offer traditional monographs and serials, but many offer datasets, multimedia collections, databases of every description, institutional repositories, and a host of other digital collections. We seem to be trying to gain access to every conceivable resource a user may ever need.

One of White's greatest concerns for our future was the potential for our services to be marginalized. If a commercial entity can provide the same quality of resources at less cost than the library, we will lose credibility and eventually be put out of business. This made me think of Google Books and Microsoft's Digital Books project. The public-domain books in these collections can be accessed by anyone, anywhere, at no cost. What does this mean for a library that also owns these titles? What if open access journals become the norm? Why would someone need a library? 
1993

The final prediction which comes from Philip Young, library director at Krannert Memorial Library, University of Indianapolis. To his credit, Young doesn't state a specific time period for his predictions. According to Young, in the foreseeable future the library will continue to be a repository for books. He believed books were still the most compact, portable, and accessible format available for linear information. Until the technology improves, e-books are unlikely to replace print books. So far this has held true. E-books have not displaced print monographs, though they are growing in number.

Like the two predictors before him, Young predicted the continued growth of electronic resources, especially for non-linear information. Electronic reference books and serials are much more likely to replace their print counterpart due to the nature of the information they provide. While many users aren't ready to read a 300-page book online, they are willing to read or print a 10-page journal article. This would probably be an accurate statement for most libraries today. The majority of libraries have far more e-journal subscriptions than print titles. Many have also begun moving to e-books or databases for their reference needs, though print reference is still readily available.

Unlike our current prophets who predict the death of the OPAC, Young believed the OPAC would become more robust. He believed libraries would offer table-of-contents information, abstracts, reviews, and even full-text searching in their OPACs. Many of our OPACs reflect Young's predictions. Some libraries subscribe to third-party services which allow them to provide cover art, book reviews, tables of contents, and abstracts for the majority of the items in our collection.

He also thought we would see great strides in artificial intelligence (AI) which would remember our past searching history, offer suggestions, and allow us to customize our search results. Though not AI per se, this ability is currently available to us through a number of the vendor databases. Most include a "My (insert vendor here) Account," feature which stores information about our search history. We can subscribe to RSS feeds to get notices of current research in our preferred subject area. To assist the searcher, many databases offer helpful search term suggestions or limiters.

Young believes the library's role will switch from one of access to one of retrieval. Libraries will no longer rely on Dewey and LC to classify monographs, but rather materials will be arranged in numeric order regardless of subject area or material type. This will make it possible for automated retrieval services to find the material more easily and deliver it to the user. A number of institutions have taken this approach to their storage facilities. For instance, Sonoma State houses over 750,000 books in a warehouse inside the library. Students can request a book from the warehouse and the automation system will retrieve it in about 15 minutes: http://library.sonoma.edu/about/ars.html. The days of an expansive physical collection may be numbered. We'll have to wait and see.

Overall, I was surprised with the accuracy of all three predictors. Many of the concepts they developed fifteen to twenty years ago are currently in practice. Though they might have gotten some of the minor details wrong, the basic principles have become reality. Which brings me back to my original question, should I believe some of the predictions I'm hearing today? After reviewing these predictions I would have to say yes, I should be concerned about present day predictions. Though they may not come to fruition, there is always the possibility they are accurate in concept if not detail. However, just because someone says the OPAC is dead doesn't mean it is doomed. In the end it is you and I as information professionals who will determine the path we take. Of course our users and those who fund us will have a powerful influence on our decisions.

I will leave you with another question. Is it the predictions that drive the changes, or does the future develop regardless of the predictions?

\section{Selected Bibliography}

Hoadley, I. "The World That Awaits Us: Libraries of Tomorrow.” Wilson Library Bulletin 61 (1986): 22-25.

White, H. S. "Libraries and Librarians in the Next Millennium." Library Journal 115:9 (1990): 54-55.

Young, P. "Visions of Academic Libraries in the Brave New Future.” In Libraries and the Future, edited by F.W. Lancaster. Binghamton, NY: Haworth, 1993. 